\title{
Türkiye'de İşletme Tarihinin Görünümü ve Gelişimi: Yönetim ve Organizasyon Kongre Bildirileri Üzerinden Bir Bakış
}

\section{The Vew and Development of Business History in Turkey: An Overview on Managemnet and Organization Congress Papers}

\author{
Osman Eroğlu a,* \\ ${ }^{a}$ Dr. Öğr. Üyesi, Mardin Artuklu, Üniversitesi, İktisadi ve İdari Bilimler Fakültesi, İşletme Bölümü, 47200, Mardin/Türkiye. \\ ORCID: 0000-0002-8149-0149
}

MAKALE BİLGİİ
Makale Geçmişi:
Başvuru tarihi: 31 Mayıs 2020
Düzeltme tarihi: 17 Ağustos 2020
Kabul tarihi: 21 Ağustos 2020
Anahtar Kelimeler:
İşletme Tarihi
Yönetim ve Organizasyon Kongreleri
Türkiye

ÖZ

Türkiye'de işletme tarihini ayrı bir disiplin olarak nitelendirmek için oldukça erken olmasına rağmen; yakın tarihte dünyada işletme tarihine artan ilgiden etkilenerek bu alan ilgi görmeye başlamıştır. $\mathrm{Bu}$ araştırmada işletme tarihinin önce kuramsal çerçevesi ortaya çıkarılmış, daha sonra Google Ngrams istatistikleri aracılığılla bu alan taranmış, ve alanın Türkiye'deki görünümü ve gelişimi 1993 yıllından beri düzenlenen Yönetim ve Organizasyon Kongre bildirileri üzerinden incelenmiştir. Bu çalışmada işletme tarihinin Türkiye'deki yakın bir kesit tanımlaması yapılarak yönetim ve organizasyon yazınına katkı sağlaması beklenmektedir.

\section{ART ICLE INFO}

Article history:

Received 31 May 2020

Received in revised form 17 August 2020

Accepted 21 August 2020

\section{Keywords:}

Business History

Management and Organization Congresses Turkey

\begin{abstract}
A B S T R A C T
Although to characterize business history as a separate discipline in Turkey is quite early; in recent years, this area has been attracting interest in the world. In this research, first the theoretical framework of business history was disclosed then through the Google Ngrams statistics this area was scanned and the view and development of the area in Turkey was observed over the Management and Organization Congress proceedings which held since 1993. In this study, with defining a proximal section of business history in Turkey, it is expected to contribute the Management and Organization's literature.
\end{abstract}

\section{Giriş}

İşletmelerin en temel amaçlarından biri varlığını sürdürmektir ve varlığını sürdürebilen işletmeler uzun ömürlü olmayı başarabilirler. Yalnız hem Türkiye'de hem de Dünya'da işletmeler için uzun ömürlü olmayı başarabilmek oldukça zor bir olgu olup bunu başarabilen işletme sayısı oldukça azdır. Örneğin, Capital Online 2010 Ocak sayısına göre Türkiye'de kurulan işletmelerin \%80'i kuruldukları ilk beş yıl içerisinde kapanmakta olup bu oran ilerleyen yıllarda artmaktadır (2010'den akt., Dil, 2016: 50). Nystrom ve Starbuck'ın (1981) çalışmalarında işletmelerin yaşam ortalamasının 25 yıl olduğunu ileri sürmüştür bunun yanında Türkiye'de ise Capital Online 2010 Ocak Sayısı'nda bu ortalama 34 yıl olarak gösterilmiştir (2010'den akt., Dil, 2016: 51). Uzun ömürlü işletmeleri inceleyen bilim dalı olarak karşımıza işletme tarihi çıkmaktadır.

Daha önceleri iktisat tarihin bir alt dalı olarak anılan işletme tarihinin ayrı bir disiplin olarak ortaya çıkmasının kökenleri Kuzey Amerika ve Batı Avrupa'ya dayanmaktadır. 1920'li yılların sonunda Amerika'da işletme tarihinin kendine özgü bir çalışma alanı olarak temeli atılmıştır. Özellikle 1960’lı yıllarla birlikte işletme tarihi geniş bir alana yayılmış, önemli araştırmalar yapılmış ve üretken bir alana

\footnotetext{
*Sorumlu yazar/Corresponding author

e-posta: osmaneroglu2181@ hotmail.com
} 
dönüşmüştür. İşletme tarihi günümüzde Business History Review ve Business History gibi uzun y1llara dayanan saygin dergileriyle (Booth ve Rowlinson, 2006:13) ve The Business History Conference ve European Business History Association tarafindan sürdürülen y1llık konferanslarla birlikte yerleşik bir bilimsel alan olarak karşımıza çıkmaktadır. Günümüz akademik dünyasında işletme tarihine duyulan ilgi artmış. Dünyanın farklı ülkelerinde işletme tarihi üzerine kongreler, konferanslar ve çalıştaylar düzenlemiş ve bu alanda çalışan akademisyenler bir araya getirilmiştir. Alanla ilgili indekslerde yapılan tarama sonucunda 2010-2016 yılları arasında yayınlanan makale sayıs1, 1950-1979 yıllarında yayınlananlardan 1.16 kat daha fazladır (Kurt, 2016).

Türkiye'de işletme tarihini ayrı bir disiplin olarak nitelendirmek için oldukça erken olmasına rağmen; yakın tarihte dünyada işletmecilik tarihine artan ilgiden etkilenerek bu alan ilgi görmeye başlamıştır. Yalova üniversitesi tarafından 2014 yıllında İşletmecilik Tarihi Çalıştayı düzenlenmiştir. Yine aynı yıl Vehbi Koç ve Ankara Araştırmaları Merkezi (VEKAM) tarafindan "Tarihin Gizli, Tarihçiliğimizin Eksik Bahçesi: İşletme Tarihi” isimli panel düzenlenmiştir. Bu çalıştaylar 2015'de "Ekonomi Tarihçilerinin Gözünden Türkiye'de Yeni Bir Disipline İlişkin Yorumlar" ve "Yönetim Alanında Kayıp Bir Aktör: Türk Sevk ve İdare Derneği" olarak düzenlenmiştir. 22. Ulusal Yönetim ve Organizasyon kongresi 2014 yıllında Konya'da düzenlenen kongrede sınıflandırmasına stratejik yönetim, insan kaynakları yönetimi, örgütsel davranış disiplinleri dışında kongre tarihinde ilk defa işletmecilik/yönetim tarihini eklemiştir. 2016 yıllında İstanbul Üniversitesi İşletme Fakültesi Dergisi işletmecilik tarihi temalı özel bir sayı basmıştır. 9 Nisan 2018 tarihinde İstanbul Üniversitesi İşletme Fakültesi'nin 50. Kuruluş Yıldönümü etkinlikleri kapsamında "Yönetim ve Tarih" konferansı düzenlenmiștir. Daha sonra konferans "İşletme Tarihi Konferansı" olarak değiştirilmiş ve ikincisi 21 Mart 2019 yıllında Marmara Üniversitesinde 2. İşletme Tarihi Konferansı olarak düzenlenmiştir. Türkiye'de 3 üniversitede işletme tarihi ders olarak lisans ve lisans üstü programlarının içeriğinde yer almaktadır (Aysan, 2013: 973). Aynı zamanda akademi dışında Türkiye'de “Osmanlı İmparatorluğu döneminden Cumhuriyet'in kurulması ve günümüze kadar ticari, ekonomik (ve kültürel) hayatın merkezinde yer alan yüz yıldır yaşattıkları önemli markaların bir araya gelmeleri ile oluşmuş" Yüzyıllık Markalar Derneği bulunmaktadır.

Bu çalışmada Türkiye'de önemli ölçüde göz ardı edilen işletme tarihinin önce kuramsal çerçevesi ortaya çıkarılmış, daha sonra Google Ngrams istatistikleri aracılığıyla bu alan taranmış, ve alanın Türkiye'deki durumu ve gelişimi 1993 y1llından beri düzenlenen en köklü kongrelerinden biri olan Yönetim ve Organizasyon Kongreleri bildirileri üzerinden içerik analizi yönteminden yararlanarak incelenmiştir. Bu çalışmada bu araştırma ile amaçlanan işletme tarihinin Türkiye'de nasıl bir görümüne ve gelişime sahip olduğu yakın dönem yazın taramasıyla ortaya çıkararak ileriki araştırmalara zemin oluşturmaktır.

\section{Kuramsal Çerçeve}

İşletme tarihi denildiği zaman akla ilk gelen işletmelerin tarihini inceleyen akademik çalışmalardır. Daha kapsamlı bir tanım olarak ișletme tarihi, işletmelerin ve sektörlerin tarihlerini kayıtlarına dayalı sistematik olarak inceleyen iktisat tarihinden ayrılmış önemli bir akademik alan karşımıza çıkmaktadır. Ancak, işletme tarihinin esasını neyin oluşturduğu dair tartışma günümüze hala devam etmektedir. Amatori ve Jones (2003)' a göre işletme tarihi, işletmelerin tarihinden bütün işletme sistemlerinin tarihiyle ilgili her konuyu kapsar. İşletme tarihinin gelişiminde kritik rol oynayan ve bir iktisat tarihçisi olan Norman Gras, işletme tarihini; "Büyük küçük, geçmişte ya da günümüzde var olan işletmelerin biyografisi." olarak tanımlar (Norman, 2009). İşletme tarihi akademik bir araştırma alanı olarak üzerinde uzun süre tartışılmış kökenleri XIX. yüzyıldaki Alman ve İngiliz çalışmalarına kadar uzanmakta olup Gras’ın 1927’ de işletmecilik tarihi kürsüsünü Harvard Üniversitesi İşletmecilik Okulu'nda kurmasıyla ortaya çıkmıştır (Booth ve Rowlinson, 2006:13, Amatori ve Jones, 2007:104, Jones vd., 2012, Berghoff, 2015).

İşletme tarihinin iktisatçılar tarafından önemsenmediği bir dönemde Gras 1939 yıllında Business and Capitalism: An Introduction to Business History (İşletme ve Kapitalizm: İşletme Tarihine Giriş) adlı işletme tarihinin ilk genel sentezi çalışmayla birlikte işletme tarihi hızla gelişmeye başlamış olup özellikle 1960'larda ve 1970'lerde oldukça üretken bir akademik alan olmuştur (Amatori ve Jones, 2007: 25-27). Alfred Chandler, Gras'la birlikte işletmec tarihine önemli katkılar sağlayıp alanın Dünya'da yaygınlaşmasını ve güçlenmesi sağlamış ve bunu yaparken Gras'ın katkılarını tamamıyla red etmemiştir. Chandler işletme tarihini iktisat kuramıyla birleştirdiği sosyoloji kuramı ile daha ileri bir kurumsal çerçeveyle geliştirmiş; ve alandaki hegemonyası otuz yıl boyunca egemen olan paradigma haline gelmiş ve disiplinin çağdaş anlamda kurucusu olarak kabul görmüştür (Amatori ve Jones, 2007:28,110, Jones ve Zneitlin, 2008: 1-2). Chandler'1n büyük işletmelerin idari üstünlükleri üzerinde duran çalışmaları alanın en önde gelen çalışmalarındandır (Chandler, $1977 \&$ 1990). Bu hegemonyanın en önemli belirtilerinden biri Chandler'ın adına öğrencileri tarafindan çalışmalarının birinci ya da ikinci paragrafında atıf yapılmasa çalışmaları alanın Dünya' daki en iyi dergisi olan Business History Rewiev'de yayınlanmayacağı hususunda uyariliyordu. Bunun sonucunda, Business History Rewiev'ı 1989 sonbahar sayısında yayınlanan tüm makalelerde Chandler'ın çalışmalarına atıf yapılmış öyle ki; Galambos'un tabiriyle: 'Business History Rewiev'da Chandler'ın çalışmasına atıf yapmak törensel bir hal almiştır ” (Amatori ve Jones, 2007:29,125).

Alanın gelișimine oldukça önemli katkılar sağlayan Gras ve Chandler birlikte yakın zamanda işletme tarihi açısından oldukça önemli sayılacak Dünya İşletme Tarihi adlı eser 2003 yıllında Amatori ve Jones tarafından kaleme alınmış ve 2007 yıllında ise Türkçeye çevrilmiştir. Eser işletme tarihinin bilimsel gelişimini farklı ülkelerde incelemiş ve alana ilgi duyan araştırmacılar için oldukça önemli ve geniş kapsamlı bir kaynak olarak karşımıza çıkmaktadır. İșletme tarihinin ABD'de ve diğer ülkelerde gelişmesi için ciddi emek harcayan Chandler düzenli olarak $A B D$ ve Britanya'yı karşılaştırıyordu (Amatori ve Jones, 2007:29,135). İşletme tarihinin ayrı bir disiplin olarak ortaya çıkması Britanya'da ABD gibi oldukça gecikmiş; 1970'li yıllarda işletme tarihine ayrılmış ilk üniversite kadrosu Glasgow Üniversitesinde oluşturulmuş ve diğer 
üniversitelerinde işletme tarihi alanında belli araştırma merkezleri kurulmaya başlamıştır (Amatori ve Jones, 2007:134).

İskandinav ülkelerinde işletme tarihi, iktisat tarihinin önemli bir dalı olarak kabul edilmekte; ABD ve Britanya'nın tersine, işletme tarihi henüz bağımsızlığını sağlayamamıştır (Amatori ve Jones, 2007:169). İsveç'te, işletme tarihi 1950'lere gelindiğinde bir bilimsel araştırma alanı olarak güçlü bir temele sahipken, Danimarka'da işletme tarihine ilişkin araştırmaların gelişmesi 1960 yılında Kristof Glaman ile başlamıştır (Amatori ve Jones, 2007:172-73). 1990'larda Almanya'da Historiker Verbans'ın (Almanya'nın Tarih Derneği) başkanı Lothar Gall gibi tanımış ve saygın bir tarihçi işletme tarihine ilgi duymaya başlamış ve alanın gelişimine önemli katkılar sağlamıştır (Amatori ve Jones, 2007:194). İtalya'da ise 1983 yıllında kurulmuş olan ASSI (İşletme Tarihi ve İncelemeler Derneği) işletme tarihi alanında en önemli rolü oynamış ve 2000'lerin başında 1980'lere göre oldukça iyi konumda olan işletme tarihi alanında Milano Üniversitesi'nde bir doktora programı açılmıştır (Amatori ve Jones, 2007:243-258).

Hidemasa Morikawa, Japonya'da kurumsal temelleri savaş sonrası atılan işletme tarihinin gelişmesine öncü olmuştur. 1964'te kurulan Business History Association (İşletme Tarihi Derneği) 1984'ten beri her y1l Japanese Yearbook on Business History (Japon İşletme Tarihi Yıllığı) adlı İngilizce kitabı yayınlamakta ve 2000 yılı itibariyle 850'den fazla üyesi bulunmaktadır (Amatori ve Jones, 2007:30811). Japonya aynı zamanda 578 yılında kurulan, literatürde dünyanın en eski işletmesi olarak kabul edilen, Budist Tapınakları İnşaat İşletmesi ve Kongo Gumi Şirketi’nin 1428 yıl yaşadıktan 2006 yılında sonra kapanmasıyla bilinen işletme tarihi açısından önemli bir ülkedir (Aile İşletmeleri Kongresi, 2012: 43).

İşletme tarihi günümüzde Business History ve Business History Review gibi önemli akademik saygınlığı dergilere sahip her yıl düzenli uluslararası kongreler ve konferansların düzenlendiği bir disiplin haline dönüşmüştür. Ülkemizde üzerinde yeterince çalışılmamış yeni gelişen bir alan olarak karşımıza çıkan işletme tarihiyle ilgili yapılan çalışmalarda ülkemizin yaşayan en eski işletmesi 1777 yılında kurulan Hacıbekir Şekerleme Şirketi'dir ve şirket yönetiminde beşinci ve altıncı kuşaklar bulunmaktadır (Güvemli, 2018: 94). Tablo 1'de Türkiye'nin en uzun ömürlü 10 işletmesi gösterilmektedir. Tabloya göre Türkiye'de uzun yaşayan işletmelerin önemli bir kısmının küçük ölçekli işletmeler olduğu ve bu uzun ömürlü işletmelerin çoğunluğunun gida sektöründe yer aldığı görünmektedir.
Tablo 1. Türkiye'nin Uzun Ömürlü 10 İşletmesi

\begin{tabular}{|c|c|c|c|}
\hline İşletmenin Adı & $\begin{array}{c}\text { Kuruluş } \\
\text { Yılı }\end{array}$ & $\begin{array}{c}\text { Kuruluş Yeri- } \\
\text { Merkez Ofis }\end{array}$ & $\begin{array}{c}\text { Ürün- } \\
\text { Hizmet }\end{array}$ \\
\hline $\begin{array}{l}\text { Ali Muhiddin } \\
\text { Hacı Bekir }\end{array}$ & 1777 & İstanbul & $\begin{array}{c}\text { Şekerleme, } \\
\text { lokum }\end{array}$ \\
\hline $\begin{array}{ll}\text { Şekerci } & \text { Cafer } \\
\text { Erol } & \end{array}$ & 1807 & İstanbul & $\begin{array}{l}\text { Şekerleme, } \\
\text { lokum }\end{array}$ \\
\hline $\begin{array}{ll}\text { Tarihi } & \text { İskele } \\
\text { Simitçisi } & \end{array}$ & 1814 & Antalya & Simit \\
\hline $\begin{array}{l}\text { Karaköy } \\
\text { Güllüoğlu }\end{array}$ & 1820 & İstanbul & $\begin{array}{c}\text { Baklava } \\
\text { ve tatlı } \\
\text { çeşitleri }\end{array}$ \\
\hline Beyaz Firın & 1836 & İstanbul & $\begin{array}{c}\text { Pasta } \\
\text { Çeşitleri }\end{array}$ \\
\hline $\begin{array}{l}\text { Dedem Osmanlı } \\
\text { Çarıkları }\end{array}$ & 1800'ler & Kahramanmaraş & $\begin{array}{c}\text { Çarık } \\
\text { Üretimi }\end{array}$ \\
\hline Kebapçı Kadir & 1851 & Isparta & Lokanta \\
\hline Petek Saraciye & 1855 & İstanbul & Saraciye \\
\hline $\begin{array}{l}\text { Tarihi } \\
\text { Kalkanoğlu } \\
\text { Pilavcıs1 }\end{array}$ & 1856 & Trabzon & Lokanta \\
\hline Gökçen Grup & 1858 & Bursa & $\begin{array}{l}\text { Bplus } \\
\text { İşletme } \\
\text { Grubu }\end{array}$ \\
\hline
\end{tabular}

Kaynak: (Dil, 2016:56)

\section{Yönetim Ve Organizasyon Kongreleri}

Türkiye'nin en köklü kongrelerinden biri olan Yönetim ve Organizayon kongresinin düzenlenmesi fikri 1992 yıllında o zaman Boğaziçi Üniversitesinde çalıșan ve Yönetim ve Organizasyon alanının saygın akademisyenlerinden biri olan Behlül Üsdiken tarafindan ortaya atılmış ve bu fikir Tamer Koçel, Beyza Oba, Hüseyin Leblebici, Oğuz Babüroğlu ve Nakiye Boyacıgiller gibi akademisyenler tarafindan destek görmüş ve ilk kongre 1993 yıllında düzenlenmiştir (Özen ve Kalemci 2009: 81). O yıldan bu yana $27 \mathrm{kez}$ aksamadan düzenlenmiş olan kongreler, her yıl faklı bir üniversitede tarafindan düzenlenen ve bildirilerin bağımsız değerlendirme kurumları tarafindan değerlendirildiği bir kurumsal yapıya kavuşmuştur. Tablo 2'de yönetim ve organizasyon kongrelerinin tarihçesi gösterilmiştir., 
Tablo 2. Yönetim ve Organizasyon Kongreleri Tarihçesi

\begin{tabular}{|c|c|c|c|}
\hline Kongre & Düzenleyen Kurum & Tarih & $\begin{array}{c}\text { Sunulan } \\
\text { Bildiri } \\
\text { Sayısı } \\
\end{array}$ \\
\hline 1 & $\begin{array}{c}\text { İstanbul Üniversitesi } \\
\text { ve Boğaziçi } \\
\text { Üniversitesi }\end{array}$ & $\begin{array}{c}20-22 \\
\text { May1s } 1993\end{array}$ & 37 \\
\hline 2 & $\begin{array}{l}\text { Dokuz Eylül } \\
\text { Üniversitesi }\end{array}$ & $\begin{array}{c}16-18 \\
\text { Mayıs } 1994\end{array}$ & 38 \\
\hline 3 & $\begin{array}{c}\text { İstanbul Teknik } \\
\text { Üniversitesi } \\
\end{array}$ & $\begin{array}{c}29-31 \\
\text { May1s } 1995 \\
\end{array}$ & 84 \\
\hline 4 & $\begin{array}{l}\text { Orta Doğu Teknik } \\
\text { Üniversitesi }\end{array}$ & $\begin{array}{c}29-31 \\
\text { Mayls } 1996\end{array}$ & 19 \\
\hline 5 & Başkent Üniversitesi & $\begin{array}{c}29-31 \\
\text { May1s } 1997 \\
\end{array}$ & 41 \\
\hline 6 & Anadolu Üniversitesi & $\begin{array}{c}21-23 \\
\text { Mayıs } 1998 \\
\end{array}$ & 31 \\
\hline 7 & $\begin{array}{c}\text { İstanbul Bilgi } \\
\text { Üniversitesi } \\
\end{array}$ & $\begin{array}{c}27-29 \\
\text { May1s } 1999 \\
\end{array}$ & 45 \\
\hline 8 & Erciyes Üniversitesi & $\begin{array}{c}25-27 \\
\text { May1s } 2000 \\
\end{array}$ & 62 \\
\hline 9 & İstanbul Üniversitesi & $\begin{array}{c}24-26 \\
\text { Mayls } 2001\end{array}$ & 72 \\
\hline 10 & Akdeniz Üniversitesi & $\begin{array}{c}23-25 \\
\text { Mayis 2002 } \\
\end{array}$ & 79 \\
\hline 11 & $\begin{array}{c}\text { Afyon Kocatepe } \\
\text { Üniversitesi }\end{array}$ & $\begin{array}{c}22-24 \\
\text { Mayls } 2003\end{array}$ & 88 \\
\hline 12 & Uludağ Üniversitesi & $\begin{array}{c}27-29 \\
\text { Mayıs } 2004\end{array}$ & 96 \\
\hline 13 & Marmara Üniversitesi & $\begin{array}{c}12-15 \\
\text { Mayls } 2005\end{array}$ & 85 \\
\hline 14 & Atatürk Üniversitesi & $\begin{array}{c}25-27 \\
\text { Mayis } 2006 \\
\end{array}$ & 103 \\
\hline 15 & Sakarya Üniversitesi & $\begin{array}{c}25-27 \\
\text { Mayıs } 2007 \\
\end{array}$ & 122 \\
\hline 16 & $\begin{array}{c}\text { İstanbul Kültür } \\
\text { Üniversitesi }\end{array}$ & $\begin{array}{c}16-18 \\
\text { May1s } 2008 \\
\end{array}$ & 141 \\
\hline 17 & $\begin{array}{c}\text { Eskişehir Osmangazi } \\
\text { Üniversitesi }\end{array}$ & $\begin{array}{c}21-13 \\
\text { Mayls } 2009\end{array}$ & 130 \\
\hline 18 & Çukurova Üniversitesi & $\begin{array}{c}20-22 \\
\text { Mayls } 2010\end{array}$ & 114 \\
\hline 19 & $\begin{array}{l}\text { Çanakkale Onsekiz } \\
\text { Mart Üniversitesi }\end{array}$ & $\begin{array}{c}24-26 \\
\text { Mayıs } 2011 \\
\end{array}$ & 134 \\
\hline 20 & $\begin{array}{c}\text { Dokuz Eylül } \\
\text { Üniversitesi } \\
\end{array}$ & $\begin{array}{c}24-26 \\
\text { Mayıs } 2012 \\
\end{array}$ & 132 \\
\hline 21 & $\begin{array}{l}\text { Dumlupinar } \\
\text { Üniversitesi }\end{array}$ & $\begin{array}{c}30-31 \\
\text { Mayis, } 1 \\
\text { Haziran } \\
2013\end{array}$ & 136 \\
\hline 22 & Selçuk Üniversitesi & $\begin{array}{c}22-24 \\
\text { Mayıs } 2014\end{array}$ & 141 \\
\hline 23 & $\begin{array}{c}\text { Muğla Sitkı Koçman } \\
\text { Üniversitesi }\end{array}$ & $\begin{array}{c}14-16 \\
\text { Mays1 } 2015\end{array}$ & 155 \\
\hline 24 & Sabancı Üniversitesi & $\begin{array}{c}29-31 \\
\text { Mayıs } 2016 \\
\end{array}$ & 119 \\
\hline 25 & Başkent Üniversitesi & $\begin{array}{c}25-27 \\
\text { Mayis } 2017 \\
\end{array}$ & 150 \\
\hline 26 & $\begin{array}{c}\text { Karadeniz Teknik } \\
\text { Üniversitesi }\end{array}$ & $\begin{array}{c}10-12 \\
\text { Mayls } 2018\end{array}$ & 123 \\
\hline 27 & İstanbul Üniversitesi & $\begin{array}{l}\text { 18-20 Nisan } \\
2019\end{array}$ & 97 \\
\hline
\end{tabular}

Yönetim ve organizasyon kongresi 24 ayrı üniversite tarafindan $27 \mathrm{kez}$ düzenlenmiştir. 1993'de düzenlenen ilk kongre İstanbul Üniversitesi ve Boğaziçi üniversitesi işbirliği ile gerçekleştirilmiştir. Bu kongrelere İstanbul Üniversitesi 1993, 2001 ve 2019 yıllarında üç kez, Dokuz Eylül Üniversitesi 1994 ve 2012 yıllarında, Başkent
Üniversitesi ise 1997 ve 2017 yıllarında iki kez ev sahipliği yapmıştır. Tablo 2'de görüldüğü gibi, kabul edilen bildiri sayısı 1993'de 37 iken göreli bir artış göstermiş ve 2019'da 97'e ulaşmıştır.

Ulusal Yönetim ve Organizasyon kongresi 2014 y1l sinıflandırmasına stratejik yönetim, insan kaynakları yönetimi, örgütsel davranış disiplinleri dişında ilk defa işletmecilik tarihini eklemiştir. 2015-2018 yılları arasında düzenlenen Ulusal Yönetim ve Organizasyon kongreleri bildirilerini stratejik yönetim, insan kaynakları yönetimi, örgütsel davranış ve işletmecilik tarihi sınıflandırmasına göre inceleyen Kaya (2019) işletmecilik tarihini \%5 oranla en son sırada yer aldığını ortaya çıkarmıştır.

Akademik alanlarda yapılan çalışmaların belirli zamanlarda incelenmesi, o alanlar hakkında kapsamlı bilgiler vermekte ve alanın genel durumunu ortaya çıkarmakta ve bu durum tespiti alanın gelişimi açısından faydalıdır. $\mathrm{Bu}$ durum Üsdiken ve Pasadoes (1993: 73) çalışmasında "stok tespiti" metaforuyla açıklanmıştır.

\section{Araştırma Yöntemi}

\subsection{Araştırmanın Amacı Ve Sorusu}

$\mathrm{Bu}$ çalışmada bu inceleme ile amaçlanan işletme tarihinin Türkiye'de nasıl bir görümüne ve gelişime sahip olduğu yakın dönem yazın taramasıyla ortaya çıkararak ileriki araştırmalara zemin oluşturmaktır. Çalışmanın temel olarak cevap aradığı sorular, Türkiye'de işletme tarihinin nasıl bir görünüme sahip olduğu, gelişiminin hangi yıllarda olduğu ve hangi konuların çalışıldığ söz konusu ise nasıl bir değişim olduğu şeklinde ifade edilir.

\subsection{Yöntem Ve Veri}

Belirli akademik alanlarda yapılmış bilimsel çalışmaları belirli bir tarihsel dönemde irdelemek için kullanılan metotlar meta-analiz, bibliyometrik analiz ve içerik analizi gibi konuya kavramsal katkı sağlayabilecek yöntemlerdir. $\mathrm{Bu}$ çalışmadaki araştırma yöntemi nitel bir yöntem olan içerik analizidir ve bu çalışmada tarihsel yazın üzerinden söylem analizi yapılmıştır.

İçerik analizi ile amaçlanan araştırma için incelenen dokümanlardan veri elde edilmesidir. Analiz edilen veriler genel bir çerçeve içinde yapılan kodlamayla kod listesi oluşturulur ve bu süreçte anlamlar ve düzenlilikler temalar altında toplanır (Merriam, 2013: 173). Daha sonra bu temalarla birlikte araştırma sorusuna cevap verecek şekilde bulgular ortaya çıkarılır.

$\mathrm{Bu}$ araştırmanın örneklemini, Türk yönetim/organizasyon yazınındaki yönetim ve organizasyon kongresinde yayınlanan bildiriler oluşturmaktadır. Aynı zamanda, Google Ngrams istatistikleri aracılığıyla işletme tarihi disiplini taranmıştır. Google Ngrams, Google Labs ve Harvard University işbirliği 1500 ve 2008 yılları arasında yayınlamış ve Google tarafından 5.2 milyon kitap içerisinde yer alan 400 milyon kelime ile ilgili istatistikler http://books.google.com/ngrams/ adresi üzerinden kullanıma açılmıştır (Özdemir ve Doğan, 2012).

\subsection{Araştırma Bulguları}

Araştırma kapsamında ilk olarak Google Ngrams ile tablo 3'de görüldüğü üzere işletme tarihi ve iktisat tarihi 
karşılaştırılması yapılmıştır. Bunun nedeni olarak işletme tarihi biliminin gelişmesinde iktisat tarihi kritik katkı sağlamıştır. Tablo 3 incelendiğinde iktisat tarihi alanı işletme tarihi alanıyla kıyaslandığında oldukça fazla sayıda kitabın yazıldığı bir alan olarak karşımıza çıkmaktadır. 1970'li yıllarla birlikte iktisat tarihinde yazılan kitap sayısında sert bir düşüş yaşanırken işletme tarihinde yazılan kitap sayısı az ama istikrarlı bir şekilde artmaktadır.

Tablo 3. İşletme Tarihi ve İktisat Tarihi Google Ngrams Karşılaştırılması

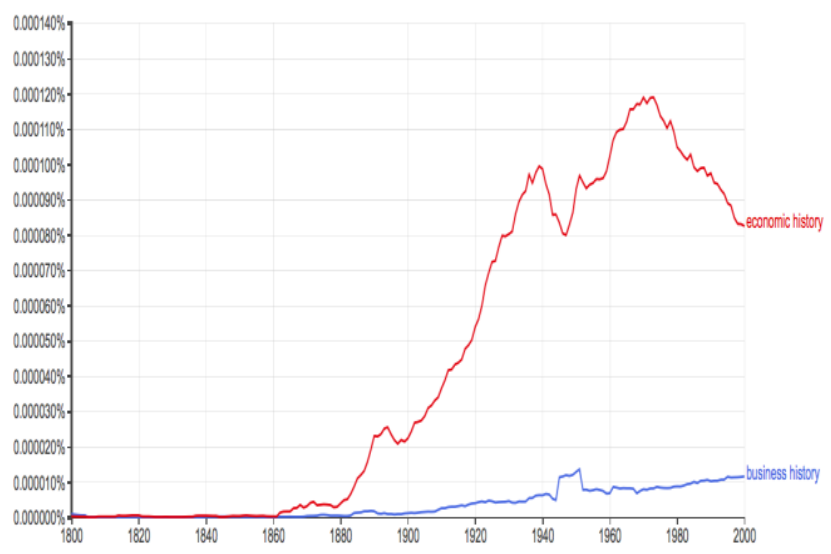

Ulusal yönetim ve organizasyon kongreleri üzerinden yapılan araştırmada incelenen 27 kongreden ilk olarak Selçuk Üniversitesi tarafindan düzenlenen 2014 yılı sınıflandırılmasına işletme tarihi eklenmiştir. Bundan dolayı çalışma 2014-2019 yılları arasındaki yayınları kapsamaktadır. Bu kapsamda çalışmada yıllara göre yayın sayısı, yazar dağılımı, en fazla katkı sağlayan yazarlar, en fazla katkı sağlayan üniversiteler, anahtar kelimeler, veri toplama yöntemi, araştırma kapsamı ve kaynakça analizi parametreleri üzerinden incelenmiştir.

\subsubsection{Yıllara Göre Yayın Sayısı}

2014-2019 yıllarındaki kongreler incelendiğinde en fazla ilginin örgütsel davranış alanına gösteridiği en az ilginin ise işletme tarihi alanına gösterildiği görülmüştür. $\mathrm{Bu}$ yıllar arasında yazılmış 32 işletme tarihi bildirisi karşımıza çıkmaktadır. Bu bildirilerin 3'ü TÜBİTAK destekli olup biri tezden üretilmiştir. İncelenen altı yılda en fazla ilgi 8 bildiri ile 2015 ve 2017 yıllarındaki kongreler olurken en az ilgi 2019 yıllında düzenlenen kongrede olmuştur. Grafik 1 'de yıllara göre işletme tarihi yayın oranları gösterilmiştir.

Grafik 1. Yıllara Göre Yayın Oranları

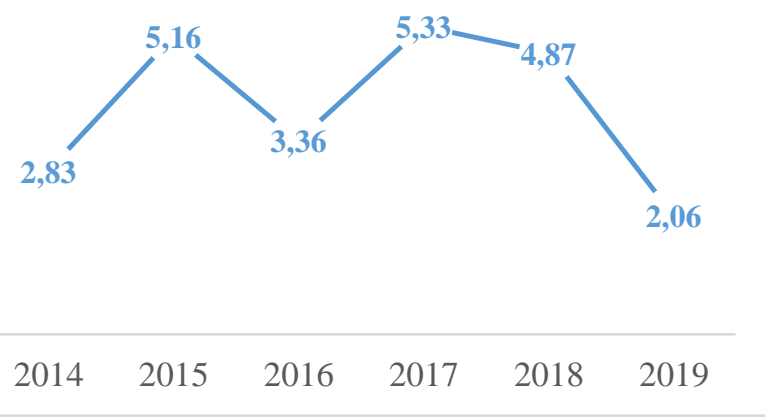

\subsubsection{Yazar Dă̆ılımı}

Yapılan incelemede yayınlanan bildirilerde çoklu yazar sayısının bildirilerin yaklaşık \% 60'ını oluşturduğu ancak en yüksek oranın \%41'le tek yazarlı bildiriler olduğu görülmektedir. Grafik 2'de ortak yazar sayıları daha detaylı olarak ortaya koyulmaktadır.

\section{Grafik 2. Ortak Yazar Sayıları}

\section{- 5 yazarl1 $=4$ yazarlı -3 yazarlı $₫ 2$ yazarlı - Tek yazarlı}

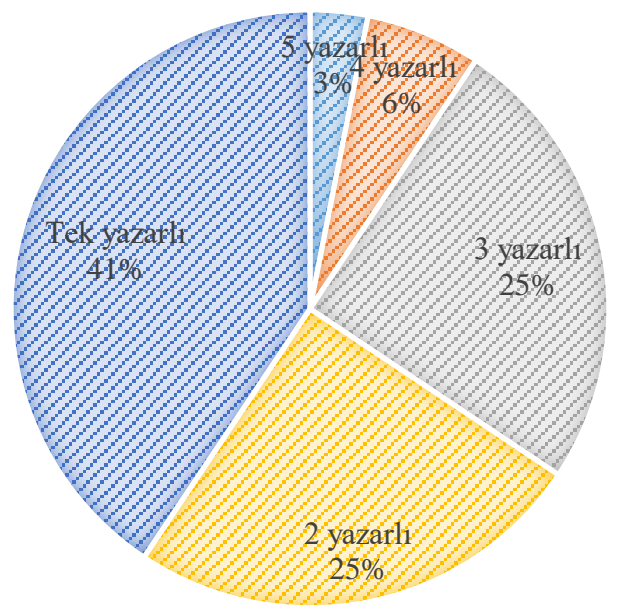

\subsubsection{En Fazla Katkı Sağlayan Yazarlar}

İşletme tarihi bilimine kongrelerdeki bildiriler üzerinden en fazla katkıyı sağlayan akademisyen olarak karşımıza Mustafa Kurt çıkmaktadır. O dönem Yalova Üniversitesi İngilizce işletme bölümünde çalışan Mustafa Kurt 2016 yıllında İstanbul Üniversitesi İşletme Fakültesi Dergisi tarafından basılan işletmecilik tarihi temalı özel bir sayının konuk editörü olarak karşımıza çıkmaktadır. Yalova üniversitesi 2014 yıllında Mustafa Kurt'unda içinde bulunduğu ekip tarafindan İşletmecilik Tarihi Çalıştayı düzenlenmiştir. İşletme tarihi bilimine olan ilginin Türkiye'de 2014 yıllı itibariyle ivme kazanmasında Mustafa Kurt'un önemli katkıları olmuştur. Grafik 3'de kongre bildirilerine en fazla katkı sağlayan diğer yazarlar gösterilmektedir.

Grafik 3. En Fazla Katkı Sağlayan Yazarlar

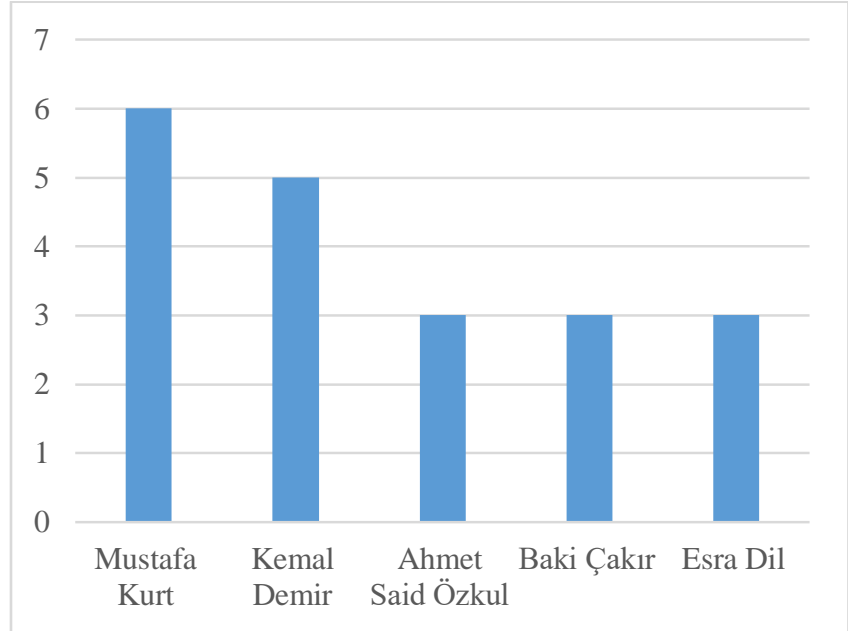




\subsubsection{En Fazla Katkı Sağlayan Üniversiteler}

Kongre bildirileri üzerinden yapılan incelemede işletme tarihi bilime en fazla katkıyı sağlayan üniversite olarak karşımıza Yalova Üniversitesi çıkmaktadır. Bunun nedeni olarak işletme tarihi alanına en fazla katkı sağlayan yazarların Yalova üniversitesinde çalışmış olmaları ve 2014 yıllında İşletmecilik Tarihi Çalıştayının bu üniversitede düzenlenmesinden kaynaklanmaktadır. Grafik 4'de katkı sağlayan diğer üniversiteler gösterilmektedir.

Grafik 4. En Fazla Katkı Sağlayan Üniversiteler

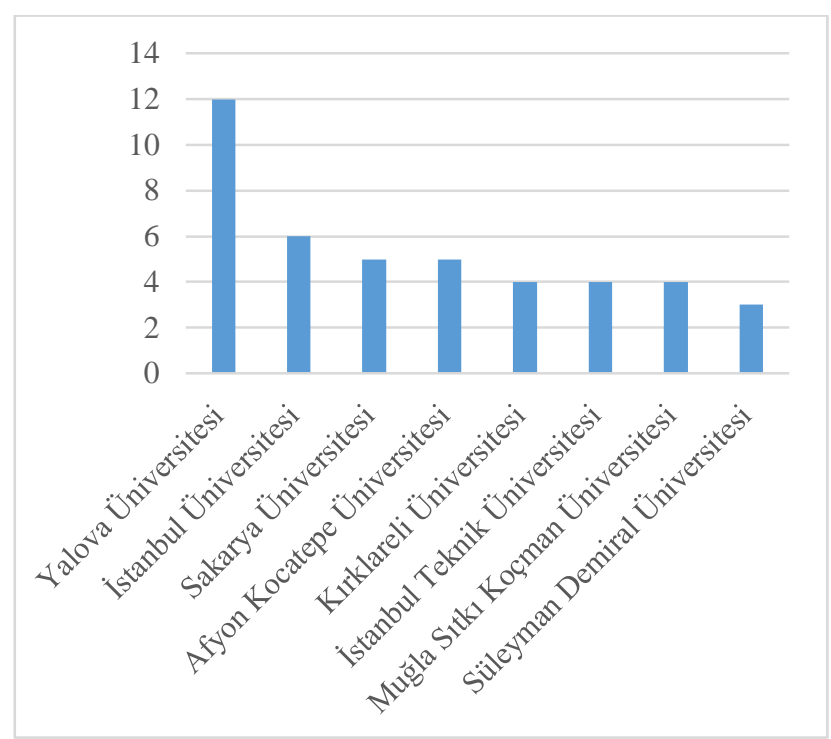

\subsubsection{Anahtar Kelimeler}

Yapılan incelemede bildirilerde ortalama üç anahtar kelime kullanıldığı ve en fazla kullanılan anahtar kelimeler olarak karşımıza Osmanlı ve Fabrika çıkmaktadır (Grafik 5).

Grafik 5. En Fazla Kullanılan Anahtar Kelimeler

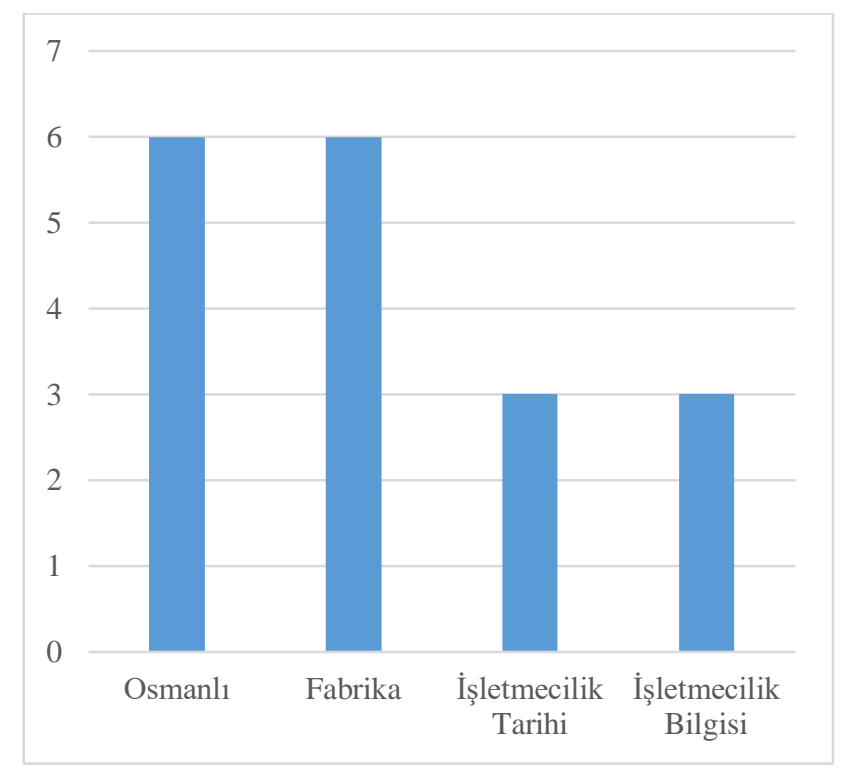

\subsubsection{Veri Toplama Yöntemi}

İncelenen bildirilerde veri toplama yöntemi olarak ağırlıklı olarak \%94 ikincil veri (Doküman İncelenmesi) kullanıldığı ortaya çıkarılmıştır (Grafik 6).
Grafik 6. Veri Toplama Yöntemleri

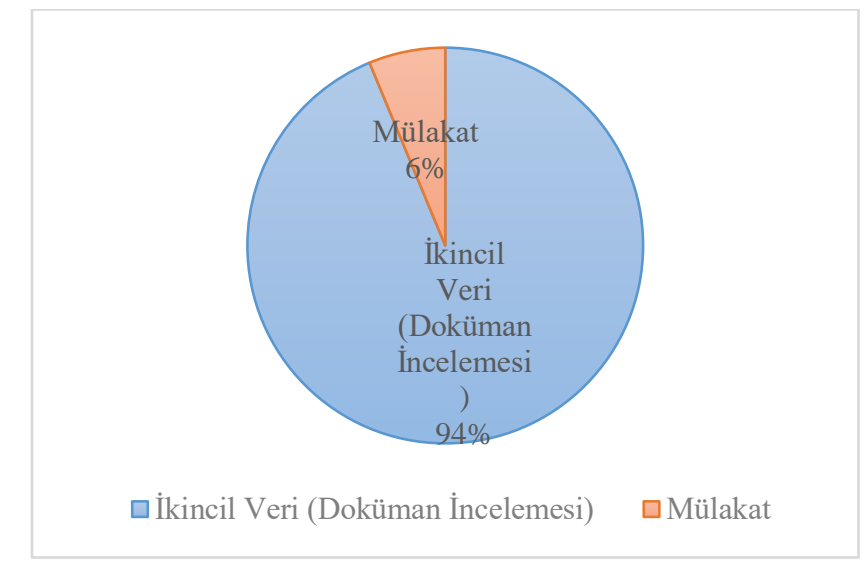

\subsubsection{Araştırma Kapsamları}

İncelenen 32 eserde en fazla kullanılan araştırma kapsamı olarak karşımıza Osmanlı dönemi çıkmaktadır (Grafik 7).

Grafik 7. Sık Kullanılan Araştırma Kapsamları

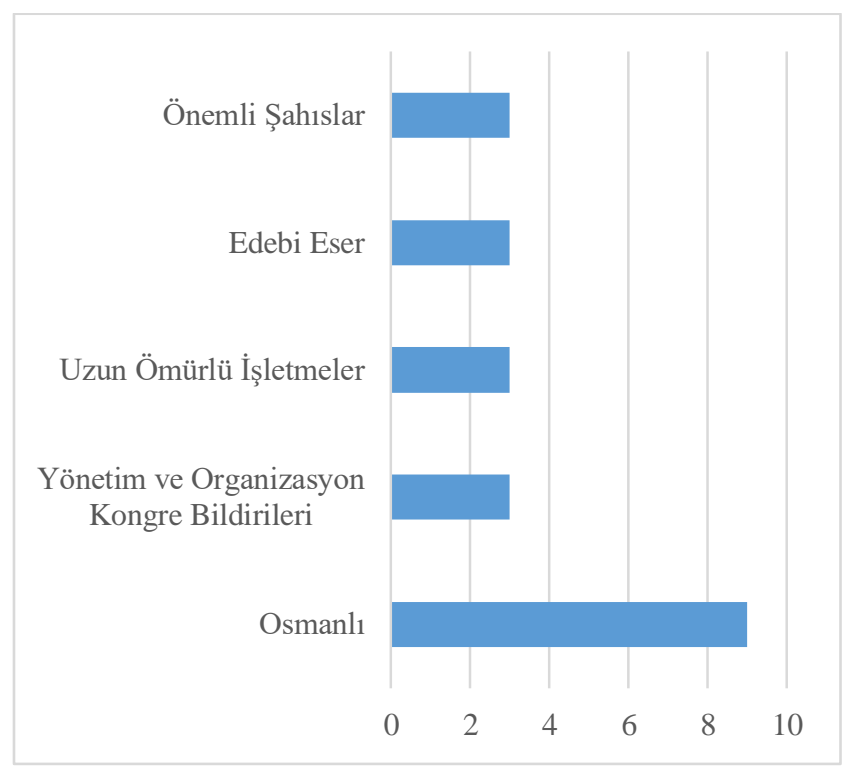

\subsubsection{Kaynakça Analizi}

Yapılan incelemede en fazla atıf alan yerli çalışma olarak karşımıza 5 atıfla Buluş ve Arıcıoğlu'nun 2005 yıllında yayınlanan "Başkaları Aracılığıyla İş Gördürmeye Tarihsel Bir Örneklem: Hereke Fabrikasında Yönetim ve Örgütlenme Anlayışı" makelesi çıkmaktadır. Bu eseri takiben 3 atıfla Aytemur'un Libra yayınevinden çıkan “Türkiye'de Yönetim Düşüncesinin Erken Dönemleri, Sümerbank (1930- 1945)" adlı kitabı gelmektedir. Aynı şekilde 3 atıfla Kurt'un "İş̧letmecilik tarihi: Özel sayıya giriş" adlı makelesi gelmektedir.

En fazla atıf alan yabancı çalışma Türkçe çevirisiyle birlikte 5 atıf alan Amatori ve Jones "Business History Around The World" adlı kitabı ve bu eseri takiben 4 atıfla Kipping ve Üsdiken tarafindan yayınlanan "History in Organization and Management Theory: More Than Meets The Eye" adlı makalesi gelmektedir. 3 atıfla Wilson ve Thomson tarafindan yazılan "The Making of Modern Management: British Management in Historical Perspective" adlı eser gelmektedir. 


\subsection{Katk1}

$\mathrm{Bu}$ çalışmada Türkiye'de işletme tarihi yazınının yakın dönem incelemesi yapılarak, alanın durumu ve gelişimiyle ilgili katkı iddiası bulunmaktadır.

\section{Değerlendirme ve Sonuç}

Bu çalışmada 2014-2019 yılları arasında düzenlenen Ulusal Yönetim ve Organizasyon Kongrelerindeki işletme tarihi sınıflandırmasındaki bildiriler içerik analizi yöntemiyle incelenmiştir. $\mathrm{Bu}$ kapsamda çalışmada yıllara göre yayın sayısı, yazar dağılımı, en fazla katkı sağlayan yazarlar, en fazla katkı sağlayan üniversiteler, anahtar kelimeler, veri toplama yöntemi, araştırma kapsamı ve kaynakça analizi parametreleri üzerinden araştırılmıştır. 2014-2019 yıllarındaki kongreler incelendiğinde en fazla ilginin örgütsel davranış alanına gösterildiği en az ilginin ise işletme tarihi alanına gösterildiği görülmüştür. İncelenen altı yılda işletme tarihine en fazla ilgi 8 bildiri ile 2015 ve 2017 y1llarındaki kongreler olurken en az ilgi 2019 y1llında düzenlenen kongrede olmuştur. Yayınlanan bildirilerde çoklu yazar sayısının bildirilerin yaklaşık \% 60 'ını oluşturduğu ancak en yüksek oranın \%41'le tek yazarlı bildiriler olduğu görülmektedir.

İşletme tarihi bilimine olan ilginin Türkiye'de 2014 yıllı itibariyle ivme kazanmasında Mustafa Kurt'un önemli katkıları olmuştur. Yapılan incelemede işletme tarihi bilime en fazla katkıyı sağlayan üniversite olarak karşımıza Yalova Üniversitesi çıkmaktadır. Bildirilerde ortalama üç anahtar kelime kullanıldı ̆̆ kelimeler olarak karşımıza Osmanlı ve Fabrika çıkmaktadır. Veri toplama yöntemi olarak ağırlıklı olarak \%94 ikincil veri (Doküman İncelenmesi) kullanıldığı ortaya çıkarılmıştır. En fazla atıf alan yerli çalışma olarak karşımıza 5 atıfla Buluş ve Arıcıoğlu'nun 2005 yıllında yayınlanan "Başkaları Aracılığıyla İş Gördürmeye Tarihsel Bir Örneklem: Hereke Fabrikasında Yönetim ve Örgütlenme Anlayışı" makelesi çıkmaktadır. En fazla atıf alan yabancı çalışma ise Türkçe çevirisiyle birlikte 5 atıf alan Amatori ve Jones "Business History Around The World" adlı kitabıdır.

İşletme tarihi alanına Türkiye'de olan ilgi 2014 yıllı itibariyle bir ivme kazanmıştır. Ancak alanın gelişebilmesi için alana yönelik lisans ve lisans üstü derslere yer verilmesi, alanda yüksek lisans ve doktora programlarının açılması ve ilgili alanda çalışan akademisyenleri bir araya getirecek çalıştay, konferans ve kongrelerin düzenlenmesi elzemdir. Bu araştırma, işletme tarihi alanına yakın zamana dair bir kesit tanımlanmasıyla kısıtlı da olsa bir katkı sunmayı amaçlamaktadır. Ayrıcı, bu çalışma gelecekteki benzer çalışmalara yapılan stok tespiti ile katkı sağlayacaktır.

\section{Kaynakça}

Amatori, F., and Jones, G. (Eds.). (2003), Business History Around The World, Cambridge University Press.

Amatori, F., and Jones, G. (2007). Dünya İşletme Tarihi, Dost Kitapevi Yayınları,

Aysan H. (2019), İşletme Okullarında işletmecilik Tarihi Eğitimi: Türkiye ve Diğer Ülkelerin Karşılaştırılması,
27. Ulusal Yönetim ve Organizasyon Kongresi, 972 976.

Berghoff, H. (2015). Business History, James D. Wright (Ed.), International Encyclopedia of Social \& Behavioral Sciences, 2nd edition, Volume 3, Elsevier.

Booth, C., Rowlinson, M. (2006). Management and organizational history: Prospects. Management and Organizational History 1(1): 5-30.

Beşinci Aile İşletmeleri Kongresi, (2012). https://www.iku.edu.tr/userfiles/AIK\%205\%20(1).pdf, (27.02.2018)

Chandler, A. D. (1977). The Visible Hand: The Managerial Revolution in American Business. Harvard University Press.

Chandler, A. D. (1990). Strategy and Structure: Chapters in the History of the Industrial Enterprise. MIT press.

Dil, E. (2016). Türkiye'de Uzun Ömürlü İşletmeler Kim? Nerede? Ne Yapıyor?, İstanbul Üniversitesi Işsletme Fakültesi Dergisi, 45 (Özel Sayı), 49-69.

Gras, N.S.B. (1934), "Business History", The Economic History Review, Vol 4. No. 4.

Güvemli O. (2018), Türkiye'nin Yaşayan En Eski İşletmesi: Hacı Bekir Şekerleme 1777-2018, Muhasebe ve Finans Tarihi Araştırmaları Derneği, Eylül (Özel Sayı). 74-104.

Jones, G. \& Zeitlin, J. (2008). "Introduction", Oxford Handbook of Business History içinde, Jones \& Zeitlin (ed.), Oxford University Press, New York, USA.

Jones, G., van Leeuwen M.H. \& Broadberry, S. (2012). "The Future of Economic, Business and Social History," Scandinavian Economic History Review, 60 (3): 225-253.

Kaya M. H. (2019). 2015-2016 Yillar1 Arasında Düzenlenen Ulusal Yönetim ve Organizasyon Kongre'lerinde Yayınlanan Bildirilerin Örgütsel Davranış Açısından Değerlendirilmesi, 27. Ulusal Yönetim ve Organizasyon Kongresi, 461-476.

Kurt, M. (2016). İşletmecilik Tarihi: Özel Sayıya Giriş. Istanbul University Journal of the School of Business, $45,2-8$.

Merriam, S. B. (2013). Nitel Verilerin Analizi. S. Turan (Ed.). Nitel Araştırma: Desen ve Uygulama İçin Bir Rehber. Ankara: Nobel Yayın, 161-198.

Nystrom, P. and Starbuck, W. (Eds) (1981). Handbook of Organizational Design, Vol. 1, Oxford University Press, Oxford.

Özdemirci, A., Doğan, B. (2012). “İdeoloji, Söylem ve Kurumsallaşma: Kurumsal Bir Alan Olarak Yönetim ve Organizasyon Yazını Örneği," XX. Ulusal Yönetim ve Organizasyon Kongresi Bildiriler Kitab1, 24-26 Mayıs, Dokuz Eylül Üniversitesi İ.İ.B.F., İzmir.

Özen Ş., Kalemci A. (2009). "Ulusal Yönetim ve Organizasyon Kongresi'nin Doğuşu, Kurumsallaşması ve Alana Etkileri," 4(1), 79-112.

Üsdiken, B. \& Pasadeos Y. (1993). “Türkiye’de Örgütler ve Yönetim Yazını.” Amme İdaresi Dergisi, 26(2), 7393. 